\title{
Age and growth in a European flagship amphibian: equal performance at agricultural ponds and favourably managed aquatic sites
}

\author{
D. Orchard $\cdot$ G. Tessa $\cdot$ R. Jehle $\mathbb{C}$
}

Received: 25 October 2018/Accepted: 29 December 2018/Published online: 14 January 2019

(C) The Author(s) 2019

\begin{abstract}
In human-modified landscapes, little is known about the influence of aquatic habitat types on the demographic structure of residing amphibian populations. In the present paper, we focus on a European flagship urodele species (the great crested newt Triturus cristatus) at the north-western range of its distribution, applying the method of skeletochronology to compare the ages of individuals retrieved from agricultural ponds with individuals retrieved from aquatic sites favourably managed for $T$. cristatus presence. Median ages ranged between 4.5 and 10.0 years depending on sex and population, and did not differ between the two site categories. Females were on average older than males at both agricultural ponds as well as favourably managed sites. Median ages at sexual maturity (3 years for females and 2 years for males) were 4 years below the most commonly observed age cohort in both sexes, suggesting that young adults regularly forgo reproduction. Mean body size did not differ between agricultural
\end{abstract}

Handling Editor: Télesphore Sime-Ngando.

D. Orchard $\cdot$ R. Jehle $(\bowtie)$

School of Environment and Life Sciences, University of Salford, Salford M5 4WT, UK

e-mail: R.jehle@salford.ac.uk

G. Tessa

Dipartimento di Scienze della Vita e Biologia dei Sistemi, Università degli Studi di Torino, Via A. Albertina, 13, 10123 Turin, Italy ponds and favourably managed sites. However, the former were characterised by a higher variance in body size, which is possibly linked to more unstable ecological conditions in agricultural settings. Taken together, our findings confirm that under suitable conditions agricultural ponds can harbour sustainable populations, an important finding for the broad-scale conservation management of $T$. cristatus which does not usually take population demographies into account.

Keywords Demography · Great crested newt · Skeletochronology · Triturus cristatus $\cdot$ Urodeles

\section{Introduction}

The spatial distribution of populations can be shaped by suitable habitat patches surrounded by unsuitable terrain (for example, in a metapopulation framework, Hanski and Gaggiotti 2004), or can vary more gradually along biotic and abiotic clines (e.g. Endler 1977). Depending on their niche breadth and the spatial scale of investigation, given taxa can also be regarded as persisting in a range of different habitat types, which influence not only their abundance but also the demographic properties of residing populations (Dunning et al. 1992; Kareiva and Wennergren 1995). That population demographies vary across 
habitats is also embedded in the framework of life history theory, which predicts a differential allocation of resources to specific life stages depending on local environmental constraints (e.g. Stearns 2000).

Ponds in agricultural landscapes are important lifesupport ecosystems for a range of plants and animals which depend on stagnant water (e.g. Williams et al. 2004; Davies et al. 2008). Temperate amphibians are a good example for such a group, and their persistence in areas used for agriculture can indeed be directly related to the availability of ponds for reproduction (Curado et al. 2011; Arntzen et al. 2017). However, while the occupancy of specific agricultural ponds by amphibians can be predicted with information about aquatic and terrestrial habitat determinants (e.g. Denoël and Ficetola 2008; Hartel et al. 2011; da Silva et al. 2012; Boissinot et al. 2019), little is known about the demographic structure of residing populations (but see, for example, Zamora-Camacho and Comas 2017; Bionda et al. 2018). Such information would be useful to assess the long-term viability of amphibians in agricultural landscapes, where the suitability of specific breeding ponds can also be compromised by eutrophication through livestock, influx of agrochemicals, and altered hydroperiods (Beja and Alcazar 2003; Mann et al. 2009; Ferreira and Beja 2013; Koumaris and Fahrig 2016; Bókony et al. 2018), in addition to habitat matrix effects that lead to increased isolation (Joly et al. 2001; Sawatzky et al. 2019).

The age of amphibians exposed to seasonal environments can be determined through skeletochronology (the counting of lines of arrested growth in bone cross sections; for a review see, for example, Sinsch 2015), and a large body of literature using this method has revealed that demographic population structures can vastly differ across latitudes and altitudes both within as well as between species (e.g. Zhang and Lu 2012; Oromí et al. 2012; Hjernquist et al. 2012; Liao et al. 2016; Sinsch and Dehling 2017; Stark and Meiri 2018). Because time-limited growth determines size which in turn is related to fecundity, longevity in amphibians can be interpreted as the result of life history strategies to maximise reproductive output under given constraints (Sinsch et al. 2010). That age structures of neighbouring populations can markedly differ from each other when situated along steep ecological clines (e.g. Miaud et al. 2001; Cogălniceanu et al. 2017) suggests that mosaics of different habitats typical for human-modified landscapes could also result in spatially heterogeneous demographies through differential local conditions.

Due to its requirement of rather large, wellvegetated ponds, the great crested newt (Triturus cristatus) is a typical inhabitant of traditionally managed agricultural areas as well as other landscapes in northern and central Europe (e.g. Hartel et al. 2010; Visser et al. 2016). Initially due to its status as a European protected species (listed in Annexes II and IV of the EU Natural Habitats Council Directive 92/43/EEC), T. cristatus has in the twenty-first century developed into a high-profile species for the use of translocation and habitat mitigation in species conservation (Edgar et al. 2005; Lewis et al. 2017; Matos et al. 2017), the use of habitat descriptors to predict occurrence and abundance in a management context (Unglaub et al. 2015, 2018; Miró et al. 2017; O'Brien et al. 2017), and the development of detection methods and associated analytical frameworks for large-scale monitoring (Biggs et al. 2015; Griffiths et al. 2015; Buxton et al. 2017; Harper et al. 2018). However, despite a disproportionate attention from conservation practitioners, T. cristatus continues to decline across most of its range (e.g. Jehle et al. 2011), among others questioning whether modern agricultural environments are suitable to form long-term demographically stable populations. The aim of the present study is to compare age at maturity, mean age, and growth of individuals residing in farm ponds with individuals breeding at aquatic sites which are favourably managed for $T$. cristatus presence.

\section{Methods}

The study took place across 13 ponds situated in Lancashire, North West England, in a roughly $36 \times 138 \mathrm{~km}$ area (Table 1). All ponds were on flat or slightly hilly terrain. Six ponds were classed as favourably managed sites (ponds in local nature reserves or gardens managed to support $T$. cristatus populations), and seven ponds were classed as agricultural sites (Table 2). That the two site categories were spatially intermixed within the study area precluded any bias, for example, due to spatial autocorrelation. Geographic distances between ponds from the two site categories exceeded the migration capabilities of $T$. cristatus, preventing that, for 
Table 1 Basic data across the 13 Triturus cristatus study populations

\begin{tabular}{|c|c|c|c|c|c|c|c|}
\hline Pond & National Grid Reference & $n$ (females) & $n$ (males) & $N(2013)$ & $N(2014)$ & $N(2015)$ & $N(2016)$ \\
\hline LHs & SD 5439242647 & 23,2 & 8,4 & - & - & - & - \\
\hline LH & SD 5372642767 & 3,0 & 7,0 & $110.1 \pm 16.6$ & $78.9 \pm 13.4$ & $39.3 \pm 5.6$ & $51.1 \pm 5.6$ \\
\hline Mhp & SD 5926036544 & 8,15 & 10,10 & $32.9 \pm 12.5$ & $129.0 \pm 170.7$ & $127.9 \pm 45.4$ & - \\
\hline Marl & SD 5938336262 & 22,5 & 20,9 & $331.4 \pm 65.7$ & $195.7 \pm 74.3$ & $261.7 \pm 70.0$ & - \\
\hline MS & SD 7677508712 & 15,12 & 19,4 & - & $225.9 \pm 92.6$ & $245.3 \pm 82.0$ & - \\
\hline SF & SD 6794007427 & 13,12 & 14,11 & $70.0 \pm 13.8$ & $123.6 \pm 55.5$ & $100.0 \pm 16.2$ & $85.8 \pm 12.3$ \\
\hline WH & SD 7195119333 & 22,7 & 22,8 & - & $417.2 \pm 159.4$ & $193.0 \pm 47.0$ & $290.2 \pm 20.5$ \\
\hline $\mathrm{AB}$ & NY 6176428207 & 0,28 & 0,25 & - & - & $282.1 \pm 15.1$ & - \\
\hline Bgp & SD 7294313483 & 17,1 & 4,2 & $42.0 \pm 5.9$ & $31.9 \pm 6.4$ & $15.0 \pm 2.2$ & $19.0 \pm 1.9$ \\
\hline GH & SD 3974107803 & 16,3 & 16,7 & $665.5 \pm 381.1$ & $753.0 \pm 29.2$ & $159.0 \pm 9.2$ & - \\
\hline HB & SD 5675712708 & 18,0 & 15,0 & - & - & - & - \\
\hline $\mathrm{RC}$ & NY 4660729327 & 22,0 & 18,0 & - & - & - & - \\
\hline $\mathrm{R}$ & SJ 6851990135 & 18,0 & 19,0 & - & - & - & - \\
\hline
\end{tabular}

The sites above and below the line represent agricultural ponds and favourably managed sites, respectively; $n$ : number of samples for skeletochronology in the two study years 2014 and 2015; $N$ : population size estimate \pm standard errors, with years in brackets. Based on the National Grid Reference, ponds can be located, for example, on Google Maps using https://gridreferencefinder.com/

example, favourably managed ponds could harbour source populations for agricultural ponds.

Field work was conducted during the breeding season (March-June) between 2013 and 2016. Study individuals were captured using dip nets and, most commonly, mesh funnel traps following Madden and Jehle (2013). SCL (snout-cloaca length, in $\mathrm{mm}$ ) was measured from the tip of the snout to the end of the cloaca using a ruler. For nine ponds (six farm ponds and three favourably managed sites), yearly population size estimates were obtained based on capturerecapture calculations using Begon's weighted mean (Begon 1979), based on photographs of variable ventral spot patterns as a means for individual recognition. Because capture sessions took place at maximally 1-week intervals, we assumed closed populations and equal detectability among individuals.

Toe clips for skeletochronology were taken in 2014 and 2015, using a sharp scalpel to remove the third digit of the left and right foot in 2014 and 2015, respectively, stored in absolute ethanol in individual 1.5-ml Eppendorf tubes. The wound was sprayed with the antiseptic Bactine, and clipped newts were immediately released back into the pond; ventral spot patterns of individuals toe clipped in 2014 and 2015 were compared to prevent the sampling of identical individuals in both years. The scalpel was sterilised using a flame, and toe clipping was performed after the newts had been measured and photographed. The third segment of the toe was used to identify the lines of arrested growth (LAGs). Preparation of the toes largely followed the standard laboratory procedures detailed by Sinsch (2015) and Angelini et al. (2015). Soft tissue was gently scraped from the amputated toe, which was placed in $3 \%$ nitric acid for $75 \mathrm{~min}$, followed by soaking in water overnight. Each toe bone was cut into sections of $10-16 \mu \mathrm{m}$ using a cryostat microtome at a temperature of $-20{ }^{\circ} \mathrm{C}$. The sections were stained with Ehrlich's haematoxylin solution until growth marks became visible (e.g. Smirina 1972). Sections were stained and mounted onto slides, and LAGs were counted using $200 \times-400 \times$ magnification. Whenever possible, age at sexual maturity was considered as the youngest age with reduced interLAG spaces ("rapprochement", see, for example, Francillon-Vieillot et al. 1990; Sinsch 2015).

The software PAST (Hammer et al. 2001) was used to conduct statistical tests. To characterise possible differences in growth rates between agricultural and favourably managed sites, we used the nonlinear regression option in Minitab 18 to construct von 
Table 2 Verbal description of aquatic breeding sites used in this study

\begin{tabular}{|c|c|}
\hline Site & Description \\
\hline LHs & $\begin{array}{l}\text { Tenanted farm managed for beef and dairy cattle. Six ponds in total, two with } T \text {. cristatus } \\
\text { presence (see LH below). Pond size approximately } 30 \times 35 \mathrm{~m}\end{array}$ \\
\hline LH & $\begin{array}{l}\text { On the same farm as LHs, at approximately } 300 \mathrm{~m} \text { distance from it separated by a road. Pond } \\
\text { size approximately } 15 \times 15 \mathrm{~m}\end{array}$ \\
\hline Mhp & $\begin{array}{l}\text { Tenanted farm managed for silage production with sheep grazing in winter. Including seven ponds, } \\
\text { five of which occupied by } T \text {. cristatus. Approximately } 25 \times 20 \mathrm{~m} \text { in size }\end{array}$ \\
\hline Marl & On the same farm as Mhp, at approximately $400 \mathrm{~m}$ distance from it. Pond size approx. $15 \times 15 \mathrm{~m}$ \\
\hline MS & $\begin{array}{l}\text { Tenanted farm, intensely grazed by beef cattle and horses. The farm includes a total of five ponds, } \\
\text { four of which have been confirmed as } T \text {. cristatus breeding ponds. One of these is a temporary pool, } \\
\text { and another is shallow and devoid of macrophyte vegetation }\end{array}$ \\
\hline SF & $\begin{array}{l}\text { Tenanted farm, grazed intensively by horses and beef cattle. Five ponds on the farm, only one suitable for } \\
T \text {. cristatus due to the presence of fish }\end{array}$ \\
\hline WH & Single pond on tenanted upland farm grazed by sheep \\
\hline $\mathrm{AB}$ & $\begin{array}{l}\text { Ornamental pond approximately } 4 \mathrm{~m} \text { in diameter, kept fish-free; situated in the parkland of a country } \\
\text { house owned by the British National Trust }\end{array}$ \\
\hline Bgp & $\begin{array}{l}\text { Four ponds }(10 \times 2 \mathrm{~m}, 7 \times 2 \mathrm{~m} \text {, and twice } 1.2 \times 1.2 \mathrm{~m}) \text { maximally } 2 \mathrm{~m} \text { apart in an urban garden } \\
\text { managed for wildlife (terrestrial habitats include dry stone walls, log piles, and a large compost heap) }\end{array}$ \\
\hline $\mathrm{GH}$ & $\begin{array}{l}\text { A large pond (approx. } 20 \times 30 \mathrm{~m} \text { ) in a private nature reserve surrounded by managed } \\
\text { woodland and meadows }\end{array}$ \\
\hline HB & $\begin{array}{l}\text { Pond on a private nature reserve originating from a former clay quarry. Main } T \text {. cristatus breeding pond } \\
\text { in of a network of seven ponds within } 100 \mathrm{~m} \text { distance }\end{array}$ \\
\hline $\mathrm{RC}$ & $\begin{array}{l}\text { Former clay extraction site, recently managed by Natural England in conjunction with a proposal } \\
\text { for a future holiday village }\end{array}$ \\
\hline $\mathrm{R}$ & $\begin{array}{l}\text { Disused brickworks site, designated SSSI (Site of Special Scientific Interest) due to prominent } \\
T \text {. cristatus presence. One of at least } 20 \text { connected ponds managed by wardens }\end{array}$ \\
\hline
\end{tabular}

The sites above and below the line represent agricultural ponds and favourably managed sites, respectively

Bertalanffy growth curves (von Bertalanffy 1938). Following Arntzen (2000) and Hemelaar (1988), we used the equation $\mathrm{SUL}_{t}=\mathrm{SUL}_{\max }-\left(\mathrm{SUL}_{\max }-\right.$ $\left.-\mathrm{SUL}_{\mathrm{met}}\right) \mathrm{e}^{-k(t-\mathrm{tmet})}$, where $\mathrm{SUL}_{t}$ is the average SUL at the age of $t$ years, $\mathrm{SUL}_{\max }$ is the estimated average maximum SUL that can be reached, $\mathrm{SUL}_{\text {met }}$ is the average SUL at metamorphosis (fixed to $35.8 \mathrm{~mm}$ following Arntzen 2000), and $t_{\mathrm{met}}$ is the proportion of the first year of life already lapsed at metamorphosis (set as 0.6 given that oviposition peaks in April and metamorphosis takes place in late summer, see Arntzen 2000); $k$ is the curvature parameter of the growth curve, describing the rate at which $\mathrm{SUL}_{\max }$ is approached.

\section{Results}

Estimated population sizes ranged across more than one order of magnitude from 15 to 753 individuals, with differences between ponds vastly exceeding any differences between agricultural ponds and favourably managed sites (Table 1). In total, we determined the age of 282 female and 252 male T. cristatus (534 individuals, 305 of which from farm ponds and 229 from favourably managed sites). An example toe cross section highlighting the counted LAGs is shown in Fig. 1. We found no significant relationships between mean age and estimated population size in males or females (Pearson correlations, $p>0.05$ in all cases, detailed data not shown), corresponding to a lack of marked temporal trends in median ages for those populations for which data from at least two successive years were available (Table 1). While our sampling dates were not sufficiently consistent to allow for 


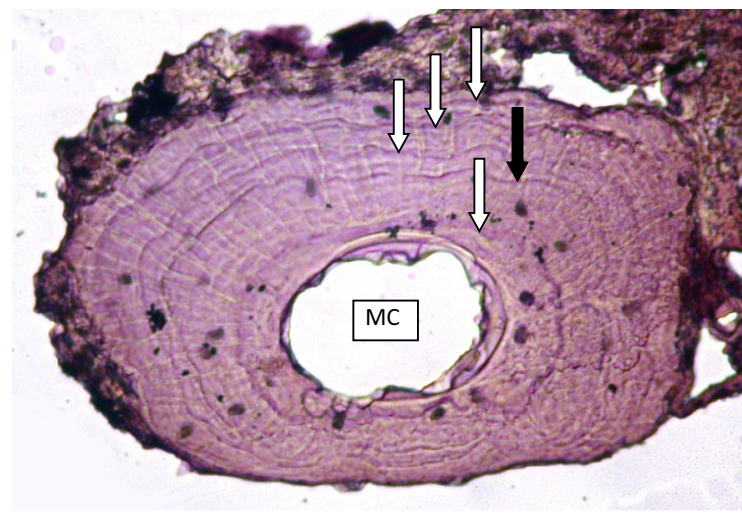

Fig. 1 Stained toe section from a male Triturus cristatus captured on May 2, 2014 (population RC). LAGs are indicated with arrows; this individual was 5 years old and sexually mature at 2 years of age (black arrow). MC medullar cavity

direct comparisons between ponds, we recorded a disproportionately high number of old individuals in captures early in the breeding season compared to later capture dates (age classes $\leq 5,6,7,8$, and $>8$ years; Kruskal-Wallis test for differences in day of first capture, females: $\chi^{2}=26.94, \quad d . f .=4, \quad p<0.01$; males $\chi^{2}=15.79$, d.f. $=4, p<0.01$ ).

\section{Age and size structure}

For females, median ages ranged between 7 and 10 years at favourably managed sites, and between 6.5 and 10 years at farm ponds; corresponding numbers for males were 5-8 years and 4.5-8 years, respectively (Table 3). For both site categories, females were on average older than males (Mann-Whitney $U$ tests: agricultural sites, $z=-3.21, p=0.002$; favourably managed sites, $z=-3.05, \quad p=0.002$; see also Fig. 2). The maximum observed age was 15 years for females (one individual from a favourably managed site) and 12 years for males (one individual from the two site categories each). Median age at sexual maturity as determined by skeletochronology was 3 years in females (range 2-4 years), and 2 years in males (range 2-4 years), a difference which was highly significant (Chi-square test for independence, d.f. $\left.=2, \chi^{2}=80.81, p<0.001\right)$. Females were significantly larger than males in both site categories (farm ponds: average SCL females $=74.45 \mathrm{~mm}$, average SCL males $=71.12 \mathrm{~mm}$; favourably managed sites: average SCL females $=75.68 \mathrm{~mm}$, average SCL males $=71.29 \mathrm{~mm} ; t$ tests, $p<0.001$ in both cases).

Comparisons between agricultural ponds and favourably managed sites

Agricultural ponds and favourably managed sites did not differ in overall ages attained (Mann-Whitney $U$ tests: females, $z=-0.12, p=0.905$; males: females, $z=-0.17, p=0.861)$, at variances which were indiscernible from each other $(F$ tests, females: $F=1.20, p=0.29$; males: $F=1.10, p=0.62$ ). Age at sexual maturity also did not differ between the two site categories (Chi-square tests for independence, females: d.f. $=2, \chi^{2}=6.07, p=0.05$; males: d.f. $=2$, $\left.\chi^{2}=3.54, p=0.17\right)$. Furthermore, mean SCL did not differ between favourably managed sites and agricultural ponds ( $t$ tests: females, $t=-1.55, p=0.112$; males, $t=0.21, p=0.825)$. Size differences could, however, also be due to differential degrees of size variation. Indeed, SCL data derived from farm ponds, where both the smallest as well as the largest individuals for both sexes were recorded, had a significantly higher variance than SCL data derived from favourably managed sites ( $F$ tests, females, $F=1.50, p=0.018$; males, $F=1.66, p=0.002$ ).

Age-size relationships characterised through von Bertalanffy growth curves reveal a large amount of variation in SCL for given ages in all categories tested (Fig. 3). Estimated asymptotic SCL was larger for agricultural ponds in both sexes, and the growth parameter $k$ was larger in favourably managed sites in females but not in males.

\section{Discussion}

Although European amphibians regularly occupy a mosaic of farmland and more natural areas (Maes et al. 2008; Couto et al. 2017; Arntzen et al. 2017), the general value of agricultural ponds as breeding habitats to support self-sustaining populations remains a matter of debate. Population genetic studies, for example, regularly demonstrate that increased agricultural activities cause a decrease in overall genetic variation, likely resulting from a combination of habitat deterioration and lack of connectivity through disappearing stepping-stone networks of ponds (e.g. Crawford et al. 2016; Lenhardt et al. 2017). Such 
Table 3 Median and range of average age across the 13 Triturus cristatus study ponds, with ranges shown in brackets

\begin{tabular}{|c|c|c|c|}
\hline Pond & Sex & Median age (2014) & Median age (2015) \\
\hline \multirow[t]{2}{*}{ LHs } & Females & $10(6-14)$ & $8.5(8-9)$ \\
\hline & Males & $8.5(5-11)$ & $4.5(4-8)$ \\
\hline \multirow[t]{2}{*}{ LH } & Females & $10(9-11)$ & - \\
\hline & Males & $8(5-10)$ & - \\
\hline \multirow[t]{2}{*}{ Mhp } & Females & $6.5(5-8)$ & $7(5-14)$ \\
\hline & Males & $5(4-11)$ & $7(6-10)$ \\
\hline \multirow[t]{2}{*}{ Marl } & Females & $7(4-11)$ & $8(7-12)$ \\
\hline & Males & $6.5(4-10)$ & $8(5-11)$ \\
\hline \multirow[t]{2}{*}{ MS } & Females & $7(5-10)$ & $6(4-7)$ \\
\hline & Males & $7(5-9)$ & $6(5-7)$ \\
\hline \multirow[t]{2}{*}{ SF } & Females & $7(3-8)$ & $6(5-8)$ \\
\hline & Males & $6(4-10)$ & $6(5-7)$ \\
\hline \multirow[t]{2}{*}{ WH } & Females & $7(3-12)$ & $7(5-9)$ \\
\hline & Males & $6(4-12)$ & $6.5(5-9)$ \\
\hline \multirow[t]{2}{*}{$\mathrm{AB}$} & Females & - & $10(7-15)$ \\
\hline & Males & - & $8(5-12)$ \\
\hline \multirow[t]{2}{*}{ Bgp } & Females & $7(5-10)$ & 7 \\
\hline & Males & $6(5-9)$ & $7.5(7-8)$ \\
\hline \multirow[t]{2}{*}{$\mathrm{GH}$} & Females & $7(4-9)$ & $7(7-8)$ \\
\hline & Males & $6(4-11)$ & $7(5-9)$ \\
\hline \multirow[t]{2}{*}{$\mathrm{HB}$} & Females & $6(5-7)$ & - \\
\hline & Males & $5(3-8)$ & - \\
\hline \multirow[t]{2}{*}{$\mathrm{RC}$} & Females & $7(4-11)$ & - \\
\hline & Males & $5(4-11)$ & - \\
\hline \multirow[t]{2}{*}{$\mathrm{R}$} & Females & $7(5-9)$ & - \\
\hline & Males & $7(4-9)$ & - \\
\hline
\end{tabular}

$\overline{\text { The sites above and below the line represent agricultural ponds and favourably managed sites, respectively. } n \text { refers to sample size }}$

evidence is, however, contrasted by the general observation that farm ponds represent important lifesupport ecosystems for the local occurrence of many amphibians, particularly when allowing for spatial connectivity (e.g. Knutson et al. 2004; Hartel et al. 2011; Boissinot et al. 2019). The present paper reveals that individuals of the great crested newt $T$. cristatus, a European flagship species for amphibian conservation, attain comparable longevity and mean growth irrespective of whether they were derived from agricultural ponds or from favourably managed breeding sites.

Care is required when interpreting our findings because the selection of particularly agricultural ponds was based on the presence of sizable $T$. cristatus populations rather than, for example, a randomisation process. As a consequence, the agricultural ponds under study represent particularly successful breeding sites in agricultural environments rather than an unbiased selection of typical ponds. Also, while skeletochronology is a well-established method to determine the age of amphibians, obtained data do not always represent truly attained ages (for example, due to endosteal resorption particularly in long-lived individuals, Wagner et al. 2011; Sinsch 2015). Triturus cristatus individuals from northern latitudes are generally characterised by higher longevity compared to individuals from southern latitudes, with mean ages ranging from 3 to 8 years depending on the population (Hagström 1977; Dolmen 1982; Francillon-Vieillot 
Fig. 2 Age structure of Triturus cristatus populations across seven agricultural ponds (top) and six favourably managed sites (bottom). Black bars: females; white bars: males
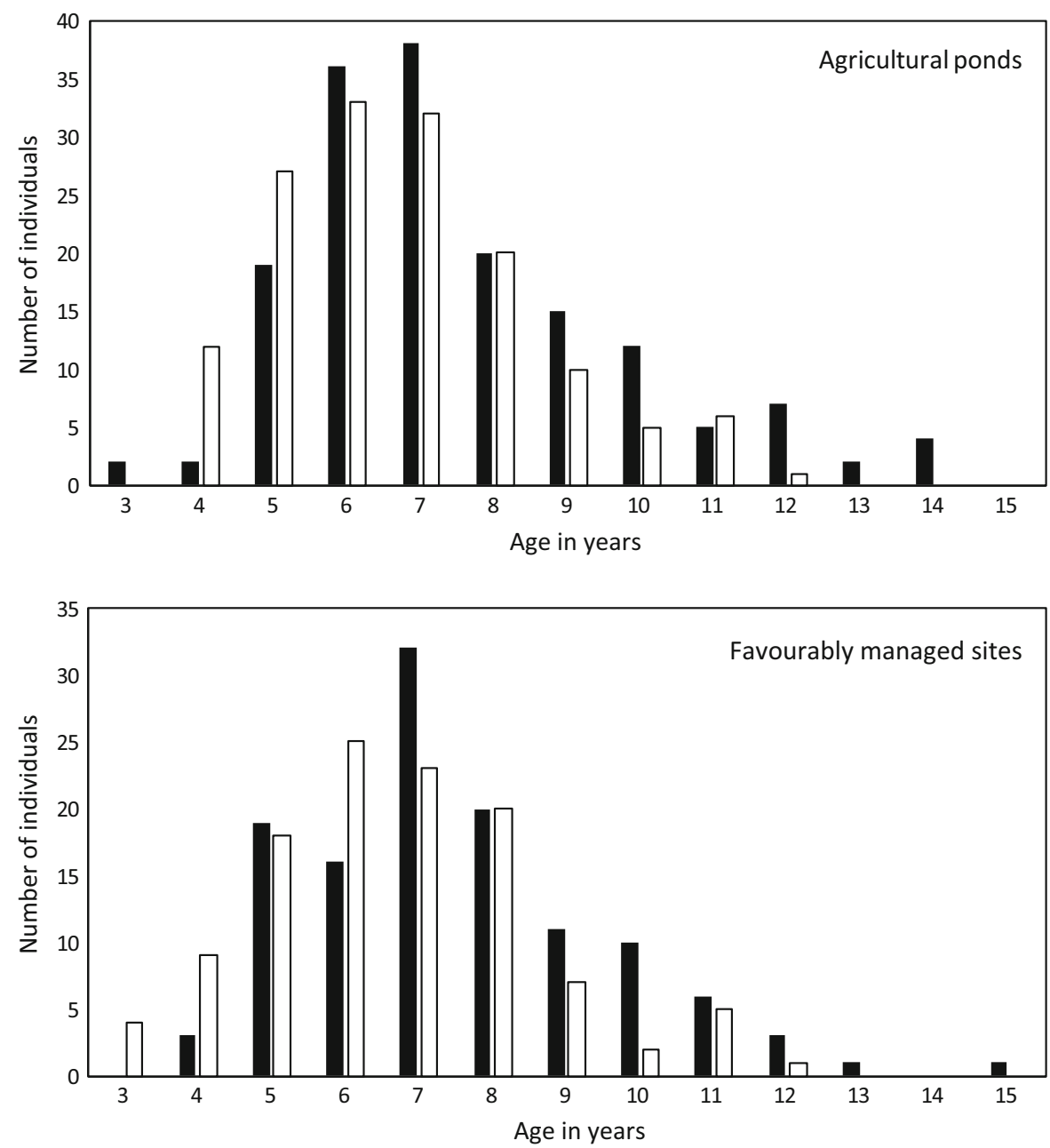

et al. 1990; Miaud et al. 1993; Sinsch et al. 2003; Unglaub et al. 2018; Palau Daval et al. 2018). Our study site is situated at the north-western part of the $T$. cristatus distribution, conforming to median ages which are at the upper range of previously published studies.

At breeding ponds, the age class represented by the highest number of individuals was six (males) and seven (females) years of age (see Fig. 2 and Table 3), which is 4 years older than the median ages at maturity for both sexes as determined by reduced inter-lag spaces ( 2 and 3 years, respectively). One explanation for low numbers of young adults would be low levels of recruitment in the years before the study was conducted. However, given that the data stem from a range of ponds across $>100 \mathrm{~km}$ in latitude, we consider it unlikely that the study populations were demographically coupled. Rather, our inferences suggest that young adults do not consistently partake in reproduction, highlighting a time lag between the onset of devoting energy to breeding to the actual participation in breeding activities. Capture-recapture studies across a range of amphibian species have revealed that particularly females do not participate in every reproductive opportunity, which is likely linked to high energetic requirements of producing eggs (Church et al. 2007; Muths et al. 2010; Cayuela et al. 2014). Our inferences suggest that not only females but also young adults regularly forgo reproduction, possibly biasing average ages as recorded at breeding ponds upwards. A combined age and sex bias of breeding frequencies might have contributed to the higher mean ages for females at our study site, which has not previously been recorded for $T$. cristatus (see 

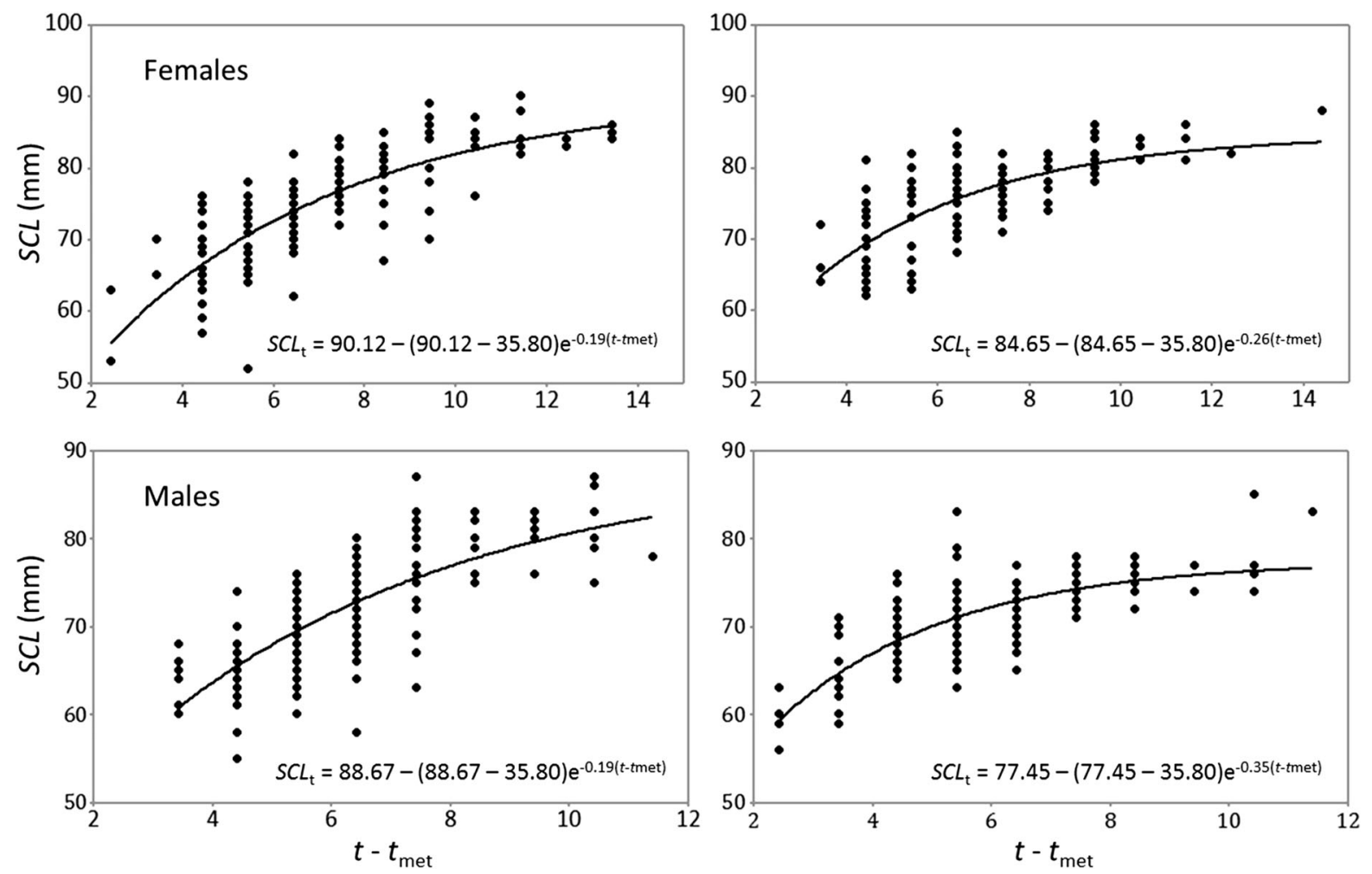

Fig. 3 Von Bertalanffy growth curve comparisons between agricultural ponds (left panel) and favourably managed sites (right panel) for Triturus cristatus. Top: females, bottom: males;

$S C L$ : snout-cloaca length, $t$ : age in years, $t_{\text {met }}$ : age at metamorphosis (set at 0.6 , for details see text)

Hagström 1977; Dolmen 1982; Miaud et al. 1993; Francillon-Vieillot et al. 1990; Sinsch et al. 2003). That older individuals tend to arrive before younger individuals has been previously reported (Sinsch et al. 2003), and Arntzen (2002) further showed that $T$. cristatus males tend to arrive at breeding ponds before females. Because tissue samples for skeletochronology were not evenly taken across the entire reproductive season, we are, however, unable to ascertain whether such phenomena have affected our inferences.

A main finding of the present study is that individuals stemming from agricultural ponds were characterised by a higher degree of variation in body size, leading to a higher estimated maximal body size in the growth models despite a lack of difference in average size. For another set of $T$. cristatus populations, body condition was inversely related to population size, which in turn was positively related to habitat suitability (Unglaub et al. 2018). Because

population sizes did not differ between agricultural ponds and favourably managed sites, it is unlikely that they can be accounted for the observed differences in body size variation. Rather, the observed higher variation in body size in farm ponds might be due to higher within- and between-year fluctuations of ecological determinants for growth at early developmental stages (e.g. temperature: Griffiths and de Wijer 1994; water level to determine density: Unglaub et al. 2018; Cayuela et al. 2018). In a similar investigation comparing urban and rural ponds, Jennette et al. (2018) found that urban storm water ponds are inhabited by on average smaller individuals at comparable age structures, which they also attributed to environmental conditions experienced at the larval and juvenile stage. Future studies could investigate whether habitat-dependent participation in breeding opportunities influences resource allocation to growth (for example, hybrid crested newts which are sterile or have low reproductive success attain larger sizes, 
Arntzen et al. 2018), and whether terrestrial environments typical for agricultural areas have an influence on growth and size (distinct habitats provided by farmland are preferentially utilised by amphibians, e.g. Salazar et al. 2016).

What can we learn from the present study for the conservation management of $T$. cristatus? That suitable agricultural ponds, although not specifically managed for $T$. cristatus, can harbour populations with demographies which are indiscernible from, for example, local nature reserves reinforces their value for sustainable local occurrences. While we did not use quantitative approaches such as population viability analysis or spatial modelling to predict the viability of our demes (e.g. Auffarth et al. 2017; for examples on T. cristatus see Halley et al. 1996; Griffiths and Williams 2000), our data do not suggest that populations inhabiting agricultural ponds are exposed to higher demographic extinction risks than populations from favourably managed sites. This is particularly important, as management practices for $T$. cristatus are increasingly based on large-scale data such as derived from environmental DNA, which are as yet largely unable to take population sizes and demographies into account (Biggs et al. 2015; Buxton et al. 2017; Harper et al. 2018). It, however, needs to be taken into account that our study was unable to assess the negative consequences of habitat fragmentation and loss, which can reduce the population persistence of $T$. cristatus as it leads to a lack of pond connectivity (e.g. Halley et al. 1996). The high protection status of $T$. cristatus coincides with similar habitat requirements of more common syntopic amphibians (Denoël et al. 2013), suggesting that preventing suitable farm ponds from deteriorating or disappearing, for example, through pond restoration or the creation of new breeding sites through agroenvironment schemes (Sayer et al. 2012; Maes et al. 2008), would benefit a range of other species.

Acknowledgements David Orchard was funded by a doctoral grant from Natural England. Toe clipping was approved by Natural England, the University of Salford ethics committee, and a personal UK Home Office licence to D. Orchard, with a project licence in partnership with the Institute of Zoology, London (licence holder T.W.J. Garner, PPL 80/2466). We are grateful to all landowners for access to their properties, and to T.W.J. Garner and J.W. Arntzen as well as two anonymous reviewers for constructive comments on an earlier manuscript version.
Open Access This article is distributed under the terms of the Creative Commons Attribution 4.0 International License (http:// creativecommons.org/licenses/by/4.0/), which permits unrestricted use, distribution, and reproduction in any medium, provided you give appropriate credit to the original author(s) and the source, provide a link to the Creative Commons license, and indicate if changes were made.

\section{References}

Angelini C, Tessa G, Bielby J, Doglio S, Favelli M, Garner TWJ, Gazzaniga E, Giacoma C, Bovero S (2015) Environmentally determined juvenile growth rates dictate the degree of sexual size dimorphism in the Sardinian brook newt. Evol Ecol 29:169-184. https://doi.org/10.1007/ s10682-014-9717-8

Arntzen JW (2000) A growth curve for the newt Triturus cristatus. J Herpetol 34:227-232

Arntzen JW (2002) Seasonal variation in sex ratio and asynchronous presence at ponds of male and female Triturus newts. J Herpetol 36:30-35

Arntzen JW, Abrahams C, Meilink WRM, Iosif R, Zuiderwijk A (2017) Amphibian decline, pond loss and reduced population connectivity under agricultural intensification over a 38 year period. Biodivers Conserv 26:1411-1430. https:// doi.org/10.1007/s10531-017-1307-y

Arntzen JW, Üzüm N, Ajduković MD, Ivanović A, Wielstra B (2018) Absence of heterosis in hybrid crested newts. PeerJ 6:e5317. https://doi.org/10.7717/peerj.5317

Auffarth J, Krug A, Pröhl H, Jehle R (2017) A geneticallyinformed population viability analysis reveals conservation priorities for an isolated European tree frog (Hyla arborea) population. Salamandra 53:171-182

Begon M (1979) Estimating animal abundance. Capture-recapture for biologists. Eduard Arnold, London

Beja P, Alcazar R (2003) Conservation of Mediterranean temporary ponds under agricultural intensification: an evaluation using amphibians. Biol Conserv 114:317-326. https://doi.org/10.1016/S0006-3207(03)00051-X

Biggs J, Ewald N, Valentini A, Gaboriaud C, Dejean T, Griffiths RA, Foster J, Wilkinson JW, Arnell A, Brotherton P, Williams P, Dunn F (2015) Using eDNA to develop a national citizen science-based monitoring programme for the great crested newt (Triturus cristatus). Biol Conserv 183:19-28. https://doi.org/10.1016/j.biocon.2014.11.029

Bionda CL, Babini S, Martino AL, Salas NE, Lajmanovich RC (2018) Impact assessment of agriculture and lifestock over age longevity and growth of populations of common toad Rhinella arenarum (anura: Bufonidae) central area of Argentina. Glob Ecol Conserv 14:e00398. https://doi.org/ 10.1016/j.gecco.2018.e00398

Boissinot A, Besnard A, Lourdais O (2019) Amphibian diversity in farmlands: combined influences of breeding-site and landscape attributes in western France. Agri Ecosyst Envriron 269:51-61. https://doi.org/10.1016/j.agee.2018. 09.016

Bókony V, Üveges B, Ujhegyi N, Verebélyi V, Nemesházi E, Csíkvári O, Hettyey A (2018) Endocrine disruptors in 
breeding ponds and reproductive health of toads in agricultural urban and natural landscapes. Sci Total Environ 634:1335-1345. https://doi.org/10.1016/j.scitotenv.2018. 03.363

Buxton AS, Groombridge JJ, Zakaria NB, Griffiths RA (2017) Seasonal variation in environmental DNA in relation to population size and environmental factors. Sci Rep 7:46294. https://doi.org/10.1038/srep46294

Cayuela H, Besnard A, Bonnaire E, Perret H, Rivoalen J, Miaud C, Joly P (2014) To breed or not to breed: past reproductive status and environmental cues drive current breeding decisions in a long-lived amphibian. Oecologia 176:107-116. https://doi.org/10.1007/s00442-014-3003-x

Cayuela H, Schmidt BR, Weinbach A, Besnard A, Joly P (2018) Multiple density-dependent processes shape the dynamics of a spatially structured amphibian population. J Anim Ecol. https://doi.org/10.1111/1365-2656.12906

Church DR, Bailey LL, Wilbur HM, Kendall WL, Hines JE (2007) Iteroparity in the variable environment of the salamander Ambystoma tigrinum. Ecology 88:891-903. https://doi.org/10.1890/06-0896

Cogălniceanu D, Băncilă RI, Plăiaşu R, Roşioru D, Merilä J (2017) Small-scale spatial and temporal variation of lifehistory traits of common frogs (Rana temporaria) in subArctic Finland. Polar Biol 40:1581-1592. https://doi.org/ 10.1007/s00300-017-2081-8

Couto AP, Ferreira E, Torres RT, Fonseca C (2017) Local and landscape drivers of pond-breeding amphibian diversity at the northern edge of the Mediterranean. Herpetologica 73:10-17. https://doi.org/10.1655/HERPETOLOGICA-D$16-00020.1$

Crawford JA, Peterman WE, Kuhns AR, Eggert LS (2016) Altered functional connectivity and genetic diversity of a threatened salamander in an agroecosystem. Landsc Ecol 31:2231-2244. https://doi.org/10.1007/s10980-016-03946

Curado N, Hartel T, Arntzen JW (2011) Amphibian pond loss as a function of landscape change-a case study over three decades in an agricultural area of northern France. Biol Conserv 144:1610-1618. https://doi.org/10.1016/j.biocon. 2011.02.011

da Silva FR, Candeira CP, de Cerqueira Rossa-Feres D (2012) Dependence of anuran diversity on environmental descriptors in farmland ponds. Biodivers Conserv 21:1411-1424. https://doi.org/10.1007/s10531-012-0252$\mathrm{Z}$

Davies B, Biggs J, Williams P, Whitfield M, Nicolet P, Sear D, Bray S, Maund S (2008) Comparative biodiversity of aquatic habitats in the European agricultural landscape. Agric Ecosyst Environ 125:1-8. https://doi.org/10.1016/j. agee.2007.10.006

Denoël M, Ficetola GF (2008) Conservation of newt guilds in an agricultural landscape of Belgium: the importance of aquatic and terrestrial habitats. Aquat Conserv Mar Freshw Ecosyst 18:714-728. https://doi.org/10.1002/aqc.853

Denoël M, Perez A, Cornet Y, Ficetola GF (2013) Similar local and landscape processes affect both a common and a rare newt species. PLoS ONE 8:e62727. https://doi.org/10. 1371/journal.pone.0062727
Dolmen D (1982) Skeletal growth marks and testis lobulation as criteria for age in Triturus spp (Amphibia) in Central Norway. Acta Zool 63:73-80

Dunning JB, Danielson BJ, Pulliam HR (1992) Ecological processes that affect populations in complex landscapes. Oikos 65:169-175

Edgar PW, Griffiths RA, Foster JP (2005) Evaluation of translocation as a tool for mitigating development threats to great crested newts (Triturus cristatus) in England 1990-2001. Biol Conserv 122:45-52. https://doi.org/10. 1016/j.biocon.2004.05.022

Endler JA (1977) Geographic variation, speciation, and clines. Princeton University Press, Princeton

Ferreira M, Beja P (2013) Mediterranean amphibians and the loss of temporary ponds: Are there alternative breeding habitats? Biol Conserv 165:179-186. https://doi.org/10. 1016/j.biocon.2013.05.029

Francillon-Vieillot HJ, Arntzen JW, Geraudie J (1990) Age, growth and longevity of sympatric Triturus cristatus, $T$. marmoratus and their hybrids (Amphibia Urodela): a skeletochronological comparison. J Herpetol 24:13-22

Griffiths RA, de Wijer P (1994) Differential effects of $\mathrm{pH}$ and temperature on embryonic development in the British newts (Triturus). J Zool 234:613-622

Griffiths RA, Williams C (2000) Modelling population dynamics of great crested newts (Triturus cristatus): a population viability analysis. Herpetol J 10:157-163

Griffiths RA, Foster J, Wilkinson JW, Sewell D (2015) Science, statistics and surveys: a herpetological perspective. J Appl Ecol 52:1413-1417. https://doi.org/10.1111/1365-2664. 12463

Hagström T (1977) Growth studies and ageing methods for adult Triturus vulgaris L. and T. cristatus Laurenti (Urodela Salamandridae). Zool Scr 6:61-68

Halley JM, Oldham RS, Arntzen JW (1996) Predicting the persistence of amphibian populations with the help of a spatial model. J Appl Ecol 33:455-470

Hammer $\varnothing$, Harper DAT, Ryan PD (2001) PAST: paleontological statistics software package for education and data analysis. Palaeontol Electron 4:4

Hanski I, Gaggiotti OE (2004) Ecology, genetics and evolution of metapopulations. Elsevier, Amsterdam

Harper LR, Lawson Handley L, Hahn C, Boonham N, Rees HC, Gough KC, Lewis E, Adams IP, Brotherton P, Phillips S, Hänfling B (2018) Needle in a haystack? A comparison of eDNA metabarcoding and targeted qPCR for detection of the great crested newt (Triturus cristatus). Ecol Evol 8:6330-6341. https://doi.org/10.1002/ece3.4013

Hartel T, Nemes S, Öllerer K, Cogălniceanu D, Moga C, Arntzen JW (2010) Using connectivity metrics and niche modelling to explore the occurrence of the northern crested newt Triturus cristatus (Amphibia, Caudata) in a traditionally managed landscape. Environ Conserv 37:195-200. https://doi.org/10.1017/S037689291000055X

Hartel T, Băncilă R, Cogălniceanu D (2011) Spatial and temporal variability of aquatic habitat use by amphibians in a hydrologically modified landscape. Freshw Biol 56:2288-2298. https://doi.org/10.1111/j.1365-2427.2011. 02655.x 
Hemelaar A (1988) Age, growth and other population characteristics of Bufo bufo from different latitudes and altitudes. J Herpetol 22:369-388

Hjernquist MB, Söderman F, Jönsson KI, Herczeg G, Laurila A, Merilä J (2012) Seasonality determines patterns of growth and age structure over a geographic gradient in an ectothermic vertebrate. Oecologia 170:641-649. https:// doi.org/10.1007/s00442-012-2338-4

Jehle R, Thiesmeier B, Foster J (2011) The crested newt: a dwindling pond dweller. Laurenti, Bielefeld

Jennette MA, Snodgrass JW, Forester DC (2018) Variation in age, body size, and reproductive traits among urban and rural amphibian populations. Urb Ecosyst. https://doi.org/ 10.1007/s11252-018-0801-7

Joly P, Miaud C, Lehmann A, Grolet O (2001) Habitat matrix effects on pond occupancy in newts. Conserv Biol 15:239-248. https://doi.org/10.1111/j.1523-1739.2001. 99200.x

Kareiva P, Wennergren U (1995) Connecting landscape patterns to ecosystem and population processes. Nature 373:299-302

Knutson MG, Richardson WB, Reineke DM, Gray BR, Parmelee JR, Weick SE (2004) Agricultural ponds support amphibian populations. Ecol Appl 14:669-684. https://doi. org/10.1890/02-5305

Koumaris A, Fahrig L (2016) Different anuran species show different relationships to agricultural intensity. Wetlands 36:731-744. https://doi.org/10.1007/s13157-016-0781-4

Lenhardt PP, Brühl CA, Leeb C, Theissinger K (2017) Amphibian population genetics in agricultural landscapes: does viniculture drive the population structuring of the European common frog (Rana temporaria)? PeerJ 5:e3520. https://doi.org/10.7717/peerj.3520

Lewis B, Griffiths RA, Wilkinson JW (2017) Population status of great crested newts (Triturus cristatus) at sites subjected to development mitigation. Herp J 27:133-142

Liao WB, Luo Y, Lou SL, Lu D, Jehle R (2016) Geographic variation in life-history traits: growth season affects age structure egg size and clutch size in Andrew's toad (Bufo andrewsi). Front Zool 13:6. https://doi.org/10.1186/ s12983-016-0138-0

Madden N, Jehle R (2013) Farewell to the bottle trap? An evaluation of aquatic funnel traps for great crested newt surveys (Triturus cristatus). Herpetol J 23:241-244

Maes J, Musters CJM, De Snoo GR (2008) The effect of agrienvironment schemes on amphibian diversity and abundance. Biol Conserv 141:635-645. https://doi.org/10.1016/ j.biocon.2007.12.018

Mann RM, Hyne RV, Choung CB, Wilson SP (2009) Amphibians and agricultural chemicals: review of the risks in a complex environment. Environ Pollut 157:2903-2927. https://doi.org/10.1016/j.envpol.2009.05.015

Matos C, Petrovan S, Ward AI, Wheeler P (2017) Facilitating permeability of landscapes impacted by roads for protected amphibians: patterns of movement for the great crested newt. PeerJ 5:e2922. https://doi.org/10.7717/peerj.2922

Miaud C, Joly P, Castanet J (1993) Variation in age structures in a subdivided population of Triturus cristatus. Can J Zool 71:1874-1879

Miaud C, Andreone F, Ribéron A, De Michelis S, Clima V, Castanet J, Francillon-Vieillot H, Guyétant R (2001)
Variations in age size at maturity and gestation duration among two neighbouring populations of the alpine salamander (Salamandra lanzai). J Zool 254:251-260. https:// doi.org/10.1017/S0952836901000760

Miró A, O’Brien D, Hall J, Jehle R (2017) Habitat requirements and conservation needs of peripheral populations: the case of the great crested newt (Triturus cristatus) in the Scottish Highlands. Hydrobiologia 792:169-181. https://doi.org/ 10.1007/s10750-016-3053-7

Muths E, Scherer RD, Lambert BA (2010) Unbiased survival estimates and evidence for skipped breeding opportunities in females. Methods Ecol Evol 1:123-130. https://doi.org/ 10.1111/j.2041-210X.2010.00019.x

O’Brien D, Hall J, Miró A, Wilkinson J (2017) Testing the validity of a commonly-used habitat suitability index at the edge of a species' range: great crested newt Triturus cristatus in Scotland. Amph-Rept 38:265-273. https://doi. org/10.1163/15685381-00003108

Oromí N, Sanuy D, Sinsch U (2012) Altitudinal variation of demographic life-history traits does not mimic latitudinal variation in natterjack toads (Bufo calamita). Zoology 115:3-37. https://doi.org/10.1016/j.zool.2011.08.003

Palau Daval N, Gardette V, Joly P (2018) Age, courtship and senescence: sexual ornaments are larger in older great crested newts. J Zool 306:156-162. https://doi.org/10. 1111/jzo.12579

Salazar RD, Montgomery RA, Thresher SE, Macdonald DW (2016) Mapping the relative probability of common toad occurrence in terrestrial lowland farm habitat in the United Kingdom. PLoS ONE 11:e0148269. https://doi.org/10. 1371/journal.pone.0148269

Sawatzky ME, Martin AE, Fahrig L (2019) Landscape context is more important than wetland buffers for farmland amphibians. Agric Ecosyst Environ 269:97-106. https:// doi.org/10.1016/j.agee.2018.09.021

Sayer CD, Andrews K, Shilland E, Edmonds N, EdmondsBrown R, Patmore I, Emson D, Axmacher JA (2012) The role of pond management for biodiversity conservation in an agricultural landscape. Aquat Consev Mar Freshw Ecosyst 22:626-638. https://doi.org/10.1002/aqc.2254

Sinsch U (2015) Skeletochronological assessment of demographic life-history traits in amphibians. Herpetol J 25:5-13

Sinsch U, Dehling JM (2017) Tropical anurans mature early and die young: evidence from eight Afromontane Hyperolius species and a meta-analysis. PLoS ONE 12:e0171666. https://doi.org/10.1371/journal.pone.0171666

Sinsch U, Lang V, Wiemer R (2003) Dynamik einer Kammmolch-Metapopulation (Triturus cristatus) auf militärischem Übungsgelände (Schmittenhöhe Koblenz): 3 Altersstruktur. Zeitschr Feldherpetol 10:229-244

Sinsch U, Marangoni F, Oromí N, Leskovar C, Sanuy D, Tejedo M (2010) Proximate mechanisms determining size variability in natterjack toads. J Zool 281:272-281. https://doi. org/10.1111/j.1469-7998.2010.00702.x

Smirina EM (1972) Annual layers in bones of Rana temporaria. Zool Zhurnal 51:1529-1534

Stark G, Meiri S (2018) Cold and dark captivity: drivers of amphibian longevity. Glob Ecol Biogeogr 27:1384-1397. https://doi.org/10.1111/geb.12804 
Stearns SC (2000) Life history evolution: successes, limitations and prospects. Naturwissenschaften 87:476-486

Unglaub B, Drechsler A, Steinfartz S, Schmidt BR (2015) Linking habitat suitability to demography in a pondbreeding amphibian. Front Zool 12:9. https://doi.org/10. 1186/s12983-015-0103-3

Unglaub B, Steinfartz S, Kühne D, Haas A, Schmidt BR (2018) The relationships between habitat suitability, population size and body condition in a pond-breeding amphibian. Basic Appl Ecol 27, pp. 20-29. https://doi.org/10.1016/j. baae.2018.01.002

Visser M, de Leeuw M, Zuiderwijk A, Arntzen JW (2016) Stabilization of a salamander moving hybrid zone. Ecol Evol 7:689-696. https://doi.org/10.1002/ece3.2676

von Bertalanffy L (1938) A quantitative theory of organic growth (inquiries on growth law II). Hum Biol 10:181-213
Wagner A, Schabetsberger R, Sztatecsny M, Kaiser R (2011) Skeletochronology of phalanges underestimates the true age of long-lived Alpine newts (Ichthyosaura alpestris). Herpetol J 21:145-148

Williams P, Whitfield M, Biggs J, Bray S, Fox G, Nicolet P, Sear D (2004) Comparative biodiversity of rivers, streams, ditches and ponds in an agricultural landscape in Southern England. Biol Conserv 115:329-341. https://doi.org/10. 1016/S0006-3207(03)00153-8

Zamora-Camacho FJ, Comas M (2017) Greater reproductive investment but shorter lifespan in agrosystem than in natural-habitat toads. PeerJ 5:e3791. https://doi.org/10.7717/ peerj.3791

Zhang L, Lu X (2012) Amphibians live longer at higher altitudes but not at higher latitudes. Biol J Linn Soc 106:623-632. https://doi.org/10.1111/j.1095-8312.2012.01876.x 